\title{
Seismic Evidence of Ancient Westward Residual Slab Subduction Beneath Southern Taiwan
}

\author{
Cheng-Horng $\operatorname{Lin}^{1,2,3, *}$ \\ ${ }^{1}$ Institute of Earth Sciences, Academia Sinica, Taipei, Taiwan, R.O.C. \\ ${ }^{2}$ Department of Geosciences, National Taiwan University, Taipei, Taiwan, R.O.C. \\ ${ }^{3}$ National Center for Research on Earthquake Engineering, National Applied Research Laboratories, Taipei, Taiwan, R.O.C.
}

Received 7 February 2013, revised 14 July 2014, accepted 11 May 2015

\begin{abstract}
The northeastern convergence of the Philippine Sea plate toward the Eurasian plate causes the major western Philippine Sea plate boundary to subduct toward the northwest or west directions. However, this phenomenon is not clearly observed along the plate boundary between Luzon and Taiwan. Careful examination of deep seismicity in the southern Taiwan area from the earthquake catalog reported by the Central Weather Bureau shows two seismic zones dipping toward the opposing directions. The first dips toward the east from the surface down to $150 \mathrm{~km}$ in depth, while the second dips westward at depths between 150 and $200 \mathrm{~km}$. These two seismic zones are confirmed further by seismogram observation and modeling results generated by two deep faults in the southern Taiwan area. The eastward seismic zone clearly results from the Eurasia plate subduction along the Manila trench, while a small section of the westward seismic zone might likely be a residual slab from the ancient subducted Philippine Sea plate. Based on the subduction speed obtained from GPS observations and the subducted Eurasian plate geometry, we can further estimate the eastward Eurasian plate subduction started at least 3.35 million years ago. This result is roughly consistent with the volcanic ages (3 - $4 \mathrm{Ma}$ ) observed in the arc between Luzon and Taiwan.
\end{abstract}

Key words: Ancient residual slab, Philippine Sea plate, Southern Taiwan

Citation: Lin, C. H., 2015: Seismic evidence of ancient westward residual slab subduction beneath southern Taiwan. Terr. Atmos. Ocean. Sci., 26, 655-661, doi: 10.3319/TAO.2015.05.11.02(TC)

\section{INTRODUCTION}

Since the Philippine Sea plate moves relatively toward the northwest direction (Seno 1977; Yu et al. 1997), some of the convergence boundary in the western part of the Philippine Sea plate is shown by subduction toward northwest or west directions. For example, northeast of Taiwan, the Philippine Sea plate subducts toward the northwest direction along the Ryukyu Trench beneath the Eurasian plate from Kyusyu to the Ryukyu Islands of Japan. South of Taiwan the westward subduction system is found down to Luzon Island of the Philippines.

However, it is very difficult to identify the westward subduction in the Taiwan area. Instead, the Eurasian plate clearly subducts eastward beneath the Philippine Sea plate from southern Taiwan to northern Luzon. Thus, it is interesting to determine possible answers for the following ques-

\footnotetext{
* Corresponding author

E-mail:lin@earth.sinica.edu.tw
}

tions. Why is there no westward subduction in Taiwan now? Was there a westward subduction before? If there was, when did it stop?

In order to improve our understanding of the questions above, we carefully examined the seismicity in the southern Taiwan area. We looked first at the deep earthquakes located by the Central Weather Bureau in the southern Taiwan area. In addition to finding an eastward subduction zone shown by a clear Benioff zone, we surprisingly identified a small cluster of earthquakes dipping westward at the end of the eastward subduction zone. We then checked the difference in seismograms generated by two closed earthquakes to distinguish exactly where they were located. We further performed ray path modeling to show the seismic wave arrivals through different ray-paths. We discuss when the westward Philippine Sea plate subduction stopped. 
The subduction system from Luzon to the Taiwan islands is one of the most complicated plate convergence zones in the western part of the "Ring of Fire". A double subduction zone with opposing convergent directions has been revealed beneath Luzon Island of the Philippines (Fig. 1). The Eurasian plate of the South China Sea is subducting eastward along the Manila Trench beneath Luzon Island, while the Philippine Sea plate subducts westward along the Eastern Luzon Trough. Two subduction zones at opposing directions are clearly shown from the seismicity profiles across Luzon Island (sections $\mathrm{C}$ and D in Fig. 1). Based on the PDE (Preliminary Determination of Epicenters) catalog reported by the USGS (http://earthquake.usgs.gov/research/data/pde.php), earthquakes with magnitudes greater than 5 demonstrate that a seismic zone dips eastward from the South China Sea to Luzon Island. The focal depths increase from the surface to a depth of more than $250 \mathrm{~km}$ (section D in Fig. 1). On the other hand, the westward subduction is shown roughly by some deep earthquakes from the Pacific Ocean to Luzon Island. The eastward subduction at Luzon Island extends continuously northward to the southern Taiwan area (sections A, B, and $\mathrm{C}$ in Fig. 1), or even further to the central Taiwan area (Lin 2000, 2002, 2009; Chen et al. 2004). It is very difficult to identify the westward Philippine Sea plate subduction in the Taiwan area. Instead of the westward subduction, the Philippine Sea plate subducts northward along the Ryukyu Trench east of Taiwan.

\section{SEISMICITY IN SOUTHERN TAIWAN}

In order to improve understanding of the southern Taiwan regional seismic characteristics we examined the earthquake catalog reported by the Central Weather Bureau since 1992 (Fig. 2). Those earthquakes were routinely located using the Taiwan dense seismic network (CWBSN, Central Weather Bureau Seismic Network) (Shin et al. 2013). This seismic network is composed of more than 80 seismic stations located throughout the Taiwan area, including all offshore islands such as Lanyu and Lutao east of Taiwan as well as Tongsa in the South China Sea (Shin et al. 2000). The Central Weather Bureau earthquake catalog provides more accurate earthquake locations than the PDE does. The smaller earthquake detection capability of the CWBSN is obviously better than that by the global seismic network.

The deep seismicity reported by the Central Weather Bureau shows two interesting seismic zones in the southern Taiwan area (Fig. 2). The eastward subduction zone beneath southern Taiwan is clearly shown by the seismicity reported by the Central Weather Bureau. The clearest seismic zone for deeper earthquakes is an east-dipping zone from $50 \mathrm{~km}$ depth down to $150 \mathrm{~km}$. This seismic zone clearly results from the Eurasian plate subduction beneath the Philippine Sea plate in southern Taiwan and it continues southward all the way to Luzon Island (Fig. 1).

It is also worth noting that some anomalous earthquakes
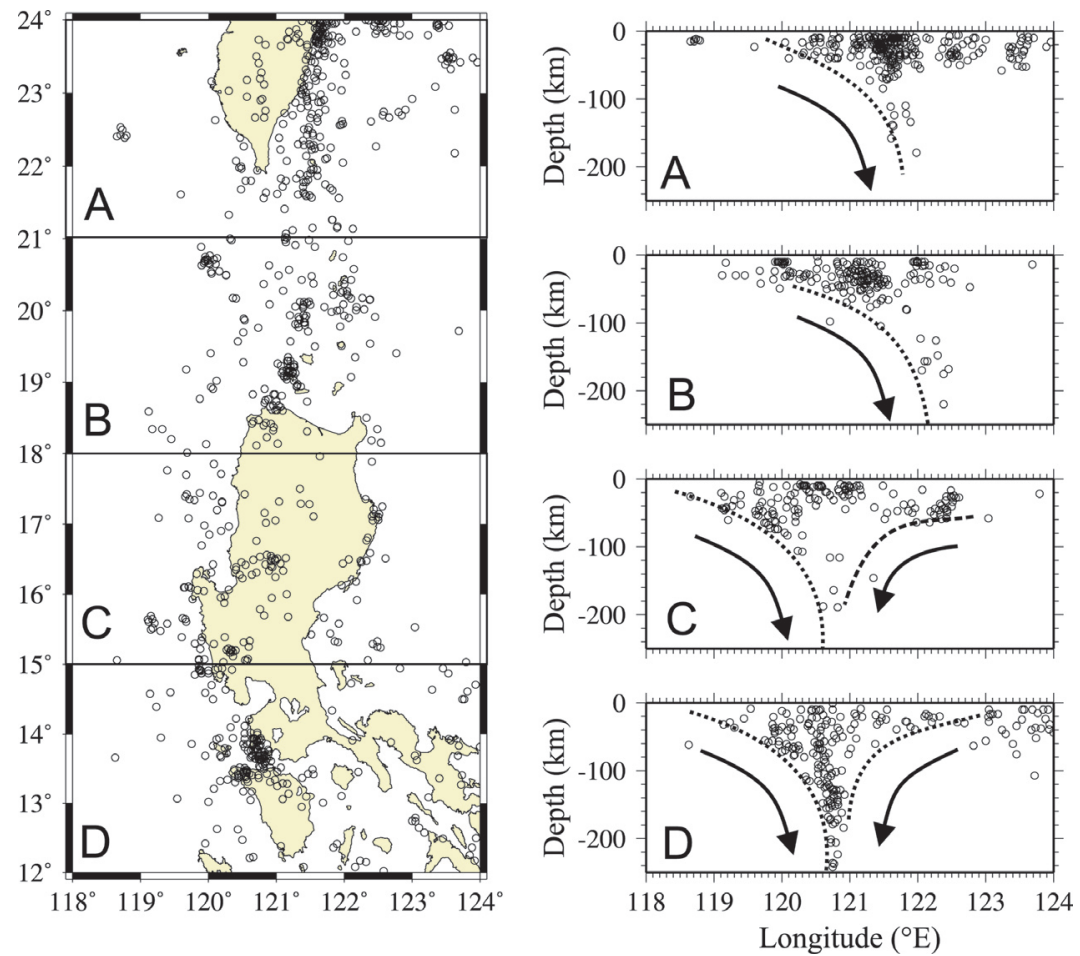

Fig. 1. Seismicity in the map (the left penal) and projected on 4 cross-sections in depth (A, B, C, and D) for showing the complicated subduction zones from Luzon to southern Taiwan (the right penal). Circles are earthquakes $(M>5)$ reported by the USGS (PDE) and arrows mark the subduction directions. 

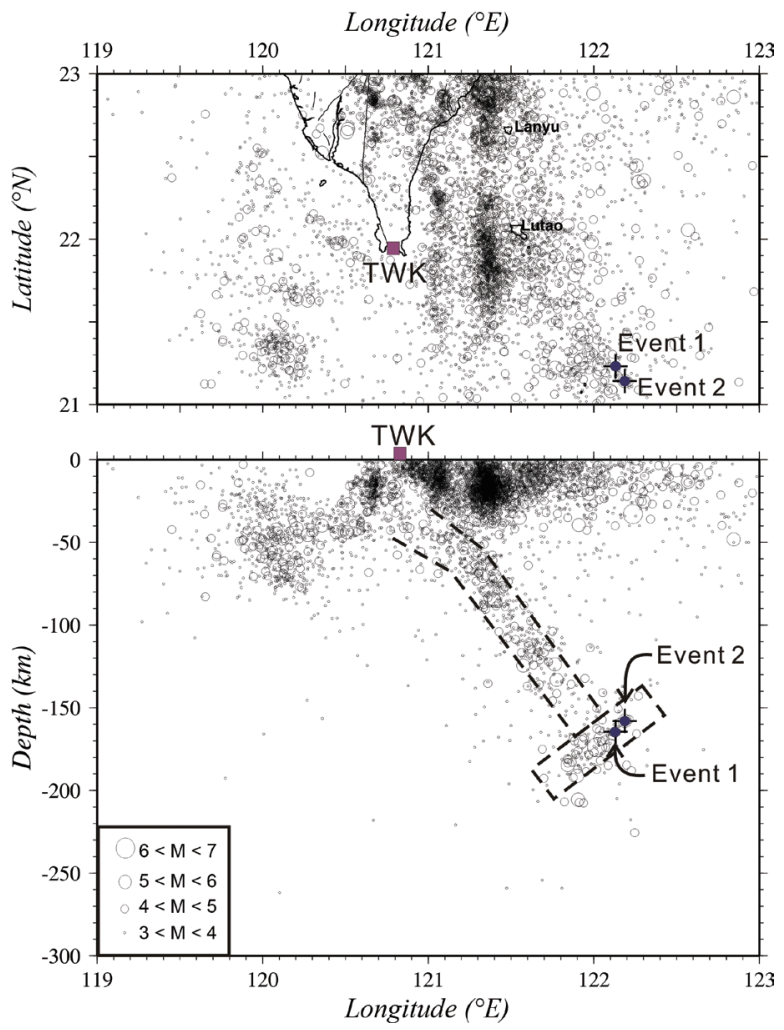

Fig. 2. Seismicity reported by Central Weather Bureau since 1992 in the southern Taiwan area. Earthquake locations (circles) are shown in the map (the upper panel) and cross-section in depth (the lower panel). Rectangular boxes show two seismic zones dipping to the opposed directions.

are clustered in depths between 150 and $200 \mathrm{~km}$, forming a seismic zone roughly dipping toward the west (Fig. 2). Although this westward seismic zone $(150-200 \mathrm{~km})$ is not as clear as that dipping east at shallower depths $(50-150 \mathrm{~km})$, the eastward seismic zone at the deeper part is significantly different from the east-dipping trend at the shallower depths $(50-150 \mathrm{~km})$. It also seems that there is a small seismic gap between the east-dipping $(50-150 \mathrm{~km})$ and the west-dipping seismic zones $(150-200 \mathrm{~km})$. This seismic gap becomes more significant if one only focuses on the earthquakes with magnitudes greater than 4.0 in Fig. 2.

\section{SEISMOGRAMS FROM TWO EVENTS}

To confirm that the west-dipping seismic zone is really distinguished from the east-dipping seismic zone, we checked two larger deep events that were close to each other but probably could generate different ray paths due to the complicated geometry of the subducted slabs. The detailed source parameters for both deep earthquakes are shown in Table 1. The first earthquake (Event 1) occurred on 26 December 2000, with the first P-waves recorded at one seismic station (TWK) on the Hengchun Peninsula, the southernmost tip of Taiwan, showing a clear pulse with some smaller later arrivals at the vertical component (Fig. 3a). This is a typical first P-wave waveform generated by a deep earthquake, directly propagated through a homogeneous upper mantle and recorded at one seismic station on the surface. The second earthquake (Event 2) occurred on 30 January 2010, with seismograms recorded at station TWK showing two clear P-waves with unambiguous arrivals separated by about $2.5 \mathrm{sec}$ (Fig. 3b). Since the second arrival was significantly later than the first one, it was hardly caused by structures nearby the source or the seismic station. The two clear P-wave phases might result from $\mathrm{P}$-waves propagated through different paths from the source to the station.

Since the seismic station (TWK) is located on the top of the subducting slab (Fig. 2), seismic P-waves propagated through two different paths within the subducted slab might take place. Lin et al. (1999) showed that two P-waves could result from seismic waves propagating through multiple paths within a subducted slab. The $1^{\text {st }} \mathrm{P}$-wave arrival was reflected from the subducted mantle at high velocity, while the $2^{\text {nd }} \mathrm{P}$-wave was propagating directly within the subducted crust at low velocity. Thus, the significant difference between the first P-waves generated by two closed earthquakes and recorded at the same station (TWK) suggests that two earthquakes, even though they were close to each other, probably could generate different ray paths due to the complicated subducted slab geometry. Although both earthquakes might occur within the westward subducted slab, they might be located inside and outside of the downward extension of the eastward subducted slab (Fig. 2).

\section{MODELING OF SEISMIC RAY PATH}

To further explain the interesting observations of different P-wave characteristics generated by two closed earthquakes, we conducted a simple subduction model for calculating the ray-paths generated by two earthquakes located inside and outside the subducted slab (Fig. 4). The subducted slab is composed of two layers dipping toward the east: the uppermost mantle and the crust. The velocity in the uppermost mantle and the subducted slab is simply assumed as $8.0 \mathrm{~km} \mathrm{sec}^{-1}$. The velocities of the subducted crust range from $6.8 \mathrm{~km} \mathrm{sec}^{-1}$ near the surface to $7.0 \mathrm{~km} \mathrm{sec}^{-1}$ at $150 \mathrm{~km}$ depth according to a previous study (Lin et al. 1999). The P-wave arrivals through different ray paths are calculated at one station on top of the subducting slab according to a two-dimensional travel-time inversion algorithm (Zelt and Smith 1992). Two earthquakes are assumed to be inside and outside the subducted slab for explaining the observations of different $\mathrm{P}$-wave characteristics from two earthquakes separated by a very short distance $(\sim 10 \mathrm{~km})$.

Figure 4a shows two groups of $\mathrm{P}$-waves generated by an earthquake within the subducted crust. The first is the directed $\mathrm{P}$-wave within the subducted crust. The second is the reflected P-wave from the subducted mantle. Therefore, two 
clear phases could be generated by the earthquake occurring on 30 January 2010 and observed at the station (TWK) on the subducting crust at the surface (Fig. 3b).

Figure $4 \mathrm{~b}$ shows only one group of ray-paths generated by an earthquake outside the subducted slab. Since the subducted crust has lower velocity than either the subducted mantle or the overlying mantle, it is difficult to observe any reflected or refracted waves from the subducted slab boundary. This is consistent with the observation of only one Pwave generated by the earthquake on 26 December 2000 and recorded at station TWK (Fig. 3a).

The observation and modeling results for two closed earthquakes around the subducted slab demonstrate that two deep earthquakes might be located inside and outside

Table 1. Source parameters of two earthquakes in southern Taiwan.

\begin{tabular}{c|ccccc}
\hline Earthquake Parameters & Year/Month/Day & N. Lat. (deg.) & E. Long. $($ deg.) & Depth $(\mathbf{k m})$ & Mag. $\left(\mathbf{M}_{\mathbf{L}}\right)$ \\
\hline Event 1 & $2000 / 12 / 26$ & 21.1428 & 122.1863 & 158 & 5.6 \\
Event 2 & $2010 / 01 / 30$ & 21.2308 & 122.1306 & 164 & 4.4 \\
\hline
\end{tabular}

(a)

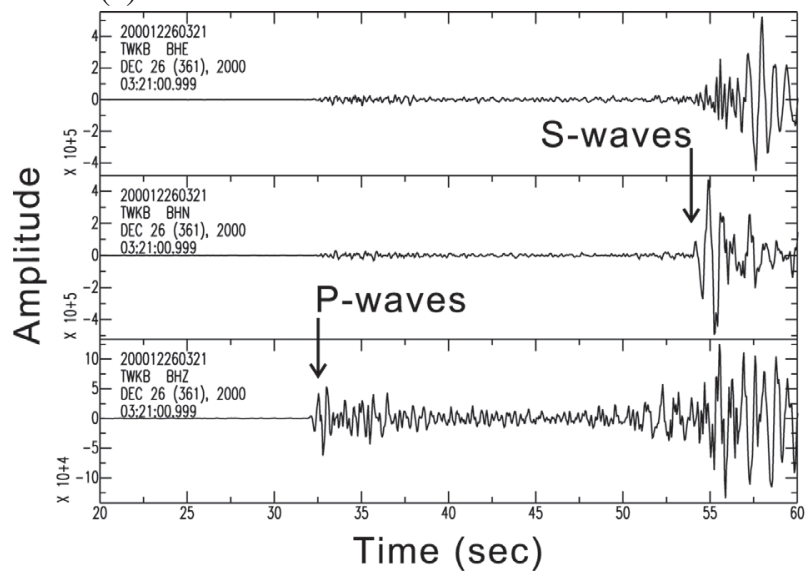

(b)

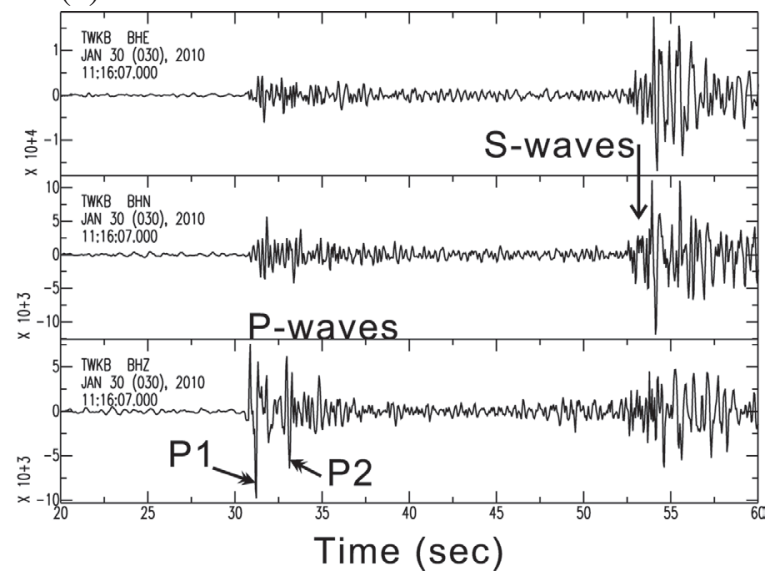

Fig. 3. Three component seismograms generated by two earthquakes located beneath southern Taiwan. The first P-and S-waves arrivals are marked by arrows.
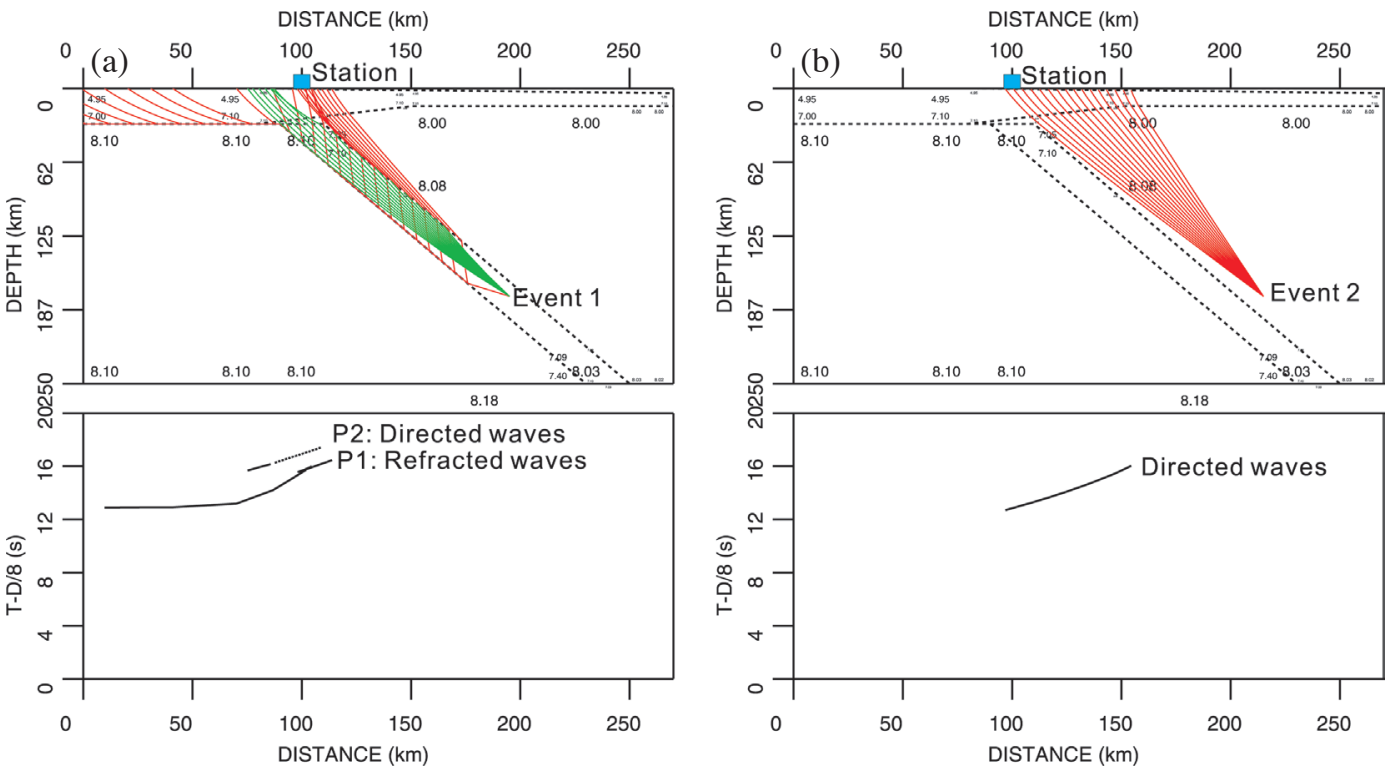

Fig. 4. Ray-path modeling of seismic waves generated by the earthquake (a) inside and (b) outside the subducting slab. 
the subducted slab downward extension (Fig. 2). When the earthquake is located within the subducted slab downward extension continued from the surface down to the earthquake (Fig. 4a), two P-waves might be observed at the station on top of the subducted crust. Only one P-wave is observed at the surface if the deep earthquake occurs outside the subducted slab downward extension (Fig. 4b).

\section{DISCUSSION}

A small section of the seismic zone dips toward the west at depths between 150 and $200 \mathrm{~km}$, considered a residual slab of the ancient subducted Philippine Sea plate. In theory, earthquakes at depths deeper than $150 \mathrm{~km}$ could not occur outside the subducted slab because the temperature in the mantle is too high to maintain the brittle characteristics required for slab rupture. Thus, an earthquake occurring outside the east-dipping subducted plate might be located at either a piece of the forearc dragged by the subducted Eurasian slab (e.g., Chemenda et al. 1997; Malavieille et al. 2002) or a major heterogeneity in the mechanical continuity of the eastward subducting Eurasian slab or another subducted slab in this area (e.g., Lallemand et al. 2001). However, the clustered seismicity geometry perpendicular to the eastward subduction of the Eurasian plate alternatively suggests that westward subduction of the Philippine Sea plate occurred in the past with the Philippine Sea plate moving northwest toward the Eurasian plate for tens of millions years. Although this phenomenon is not observed on the surface along the plate boundary between Luzon and Taiwan, the westward subduction of the Philippine Sea plate beneath the central part of Luzon Island is clearly identified by the Benioff zone at section D in Fig. 1. Such a westward subduction might possibly extend to the north to southern Taiwan before the eastward subduction of the Eurasian plate started several million years ago.

One might estimate that when the eastward subduction started according to the subducting velocity and the maximum depth of the subducted Eurasian plate slab. The eastward Eurasian plate subduction ends roughly at $\sim 150 \mathrm{~km}$ depth where the westward Philippine Sea plate subducted slab is found (Fig. 2). The total length of the subducted slab will then be $233.28 \mathrm{~km}$ using a dipping angle of 50 degrees. The average Eurasian plate motion with respect to the global coordinator can be estimated at the Penghu Island GPS station, Taiwan Strait (Fig. 5a). Although the total Eurasian plate motion at Penghu is $3.2 \mathrm{~cm} \mathrm{yr}^{-1}$ toward the southeastern direction, the eastward component is about $2.76 \mathrm{~cm} \mathrm{yr}^{-1}$. The GPS station observation at Lanyu Island on the Luzon volcanic arc shows the Philippine Sea plate moving toward the west at about $4.19 \mathrm{~cm} \mathrm{yr}^{-1}$ with respect to the global coordinator (Fig. 5b). Thus, if one considers that plate movement of about $6.95 \mathrm{~cm} \mathrm{yr}^{-1}$ occurred in the past few million years this plate has totally subducted eastward beneath the Philippine Sea plate, then the subduction process with a dipping angle of $\sim 50$ degrees toward the east would take at least $\sim 3.35$ million years from the surface down to $150 \mathrm{~km}$ in depth. In other words, the Philippine Sea plate subduction might stop with the eastward Eurasian plate subduction starting almost simultaneously at least 3.35 million years ago. This result is roughly consistent with the volcanic ages (3 - $4 \mathrm{Ma}$ ) found in the area between the northern Luzon and southern Taiwan area (Yang et al. 1996).

This seismic zone dipping to the west might be caused (a)
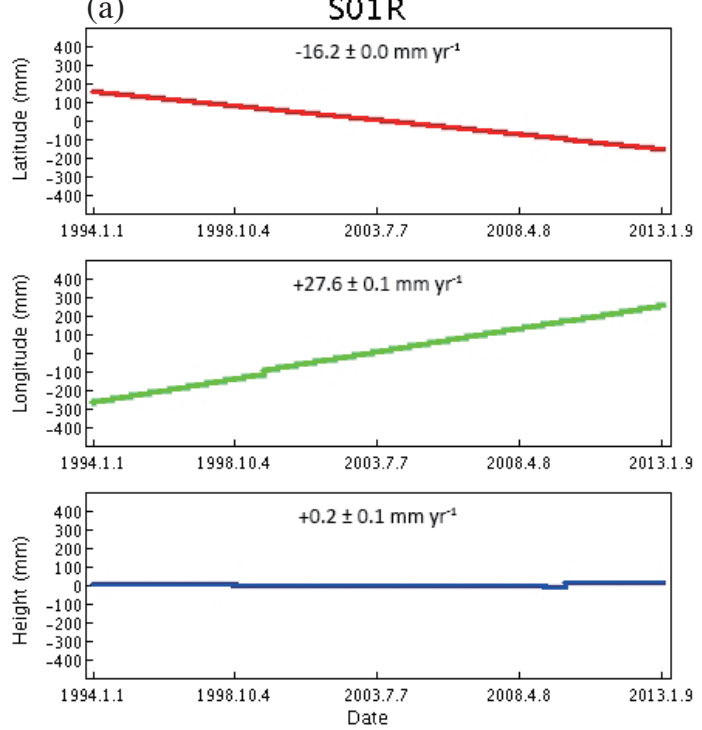

(b)
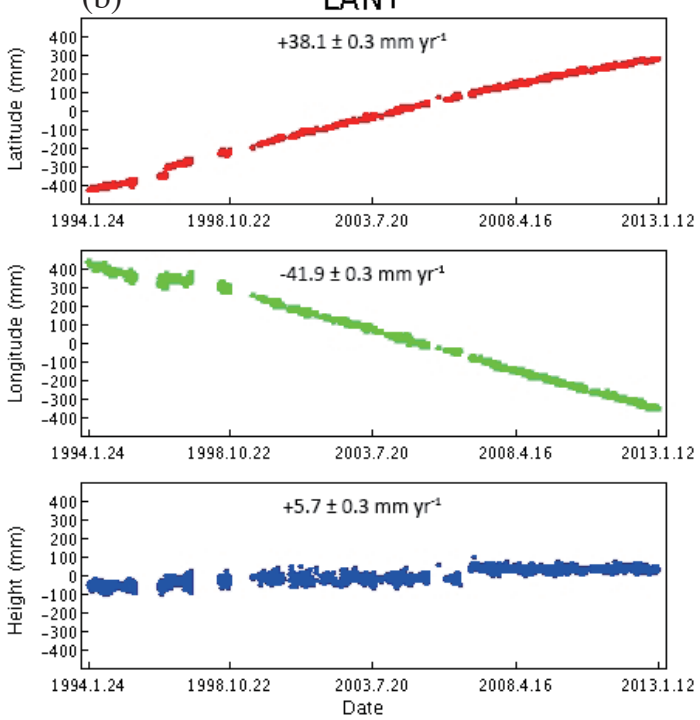

Fig. 5. Crustal deformation observed at (a) the Penghu island (S01R) of Taiwan Strait and (b) Lanyu island (LANY) of the Luzon volcanic arc since 1994 (http://gps.earth.sinica.edu.tw). The average velocity at S01R is about $3.2 \mathrm{~cm} \mathrm{yr}^{-1}$ toward the southeast and that at LANY is $5.66 \mathrm{~cm} \mathrm{yr}{ }^{-1}$ toward the northwest. 
by direct contact with the eastward Eurasian plate subducting slab, which is colder and stronger than the ancient subducted slab. The residual section of the ancient subducted Philippine Sea plate might be colder than any other sections of the subducted slab due to direct contact with the eastward subducted slab, which is still colder than the surrounding mantle (Fig. 6). The subducting Eurasian slab pushes and creates strong stress on the residual slab, and then produces earthquakes within the cold ancient slab. Thus, two seismic zones dipping to opposing directions can be observed beneath the southern Taiwan area (Fig. 2). The seismic gap between both slabs shown in Fig. 1 might result from the strength difference. The eastward Eurasian plate subduction is colder and stronger than the westward subducted slab of the ancient Philippine Sea plate, and thus no significant earthquakes occur within the bottom of the Eurasian plate when it collides with the ancient Philippine Sea plate.

\section{CONCLUSION}

Examination of deep seismicity in the southern Taiwan area shows two seismic zones dipping in opposing directions. In addition to the eastward subduction from the surface down to $150 \mathrm{~km}$, there is another seismic zone dipping to the west at depths between 150 and $200 \mathrm{~km}$. These two seismic zones were confirmed by seismogram observations and modeling results generated by two deep earthquakes located inside and outside of the subducted slab downward extension. The eastward seismic zone clearly results from the Eurasian plate subducton along the Manila trench, while the westward seismic zone might likely be a residual slab

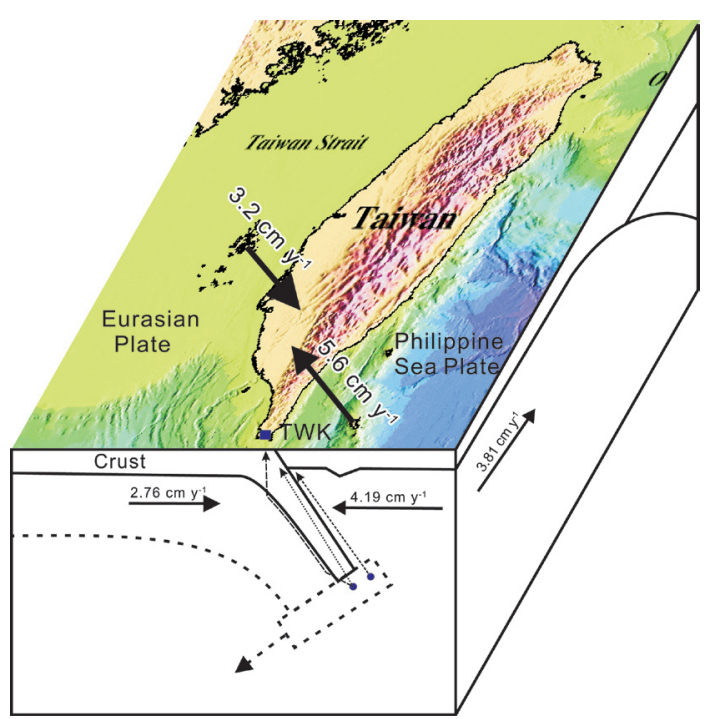

Fig. 6. Tectonic model for showing the subduction system in southern Taiwan. Arrows with solid lines show the averaged plate motions in different directions, and arrows with dashed lines indicate multiple ray paths from the earthquake to the seismic station. Dashed box with an arrow marks the ancient subducted Philippine Sea plate. from the ancient Philippine Sea plate subducted before. We further estimate Philippine Sea plate subduction stopped and the eastward Eurasian plate subduction started almost simultaneously at least 3.35 million years ago. This is based on the subduction speed from GPS observations and the geometry of the subducted Eurasian plate. This result is roughly consistent with the volcanic ages (3 - $4 \mathrm{Ma}$ ) found in the area between Luzon and Taiwan.

Acknowledgements The author would like to thank the Central Weather Bureau of Taiwan for providing seismic data and Long-Chen Kuo for providing the calculated GPS results in Taiwan. The valuable comments and suggestions by S. Lallemand and the other Anonymous Reviewer are appreciated. Financial support from the National Science Council of Taiwan is greatly appreciated.

\section{REFERENCES}

Chemenda, A. I., R. K. Yang, C. H. Hsieh, and A. L. Groholsky, 1997: Evolutionary model for the Taiwan collision based on physical modelling. Tectonophysics, 274, 253-274, doi: 10.1016/S0040-1951(97)00025-5. [Link]

Chen, P. F., B. S. Huang, and W. T. Liang, 2004: Evidence of a slab of subducted lithosphere beneath central Taiwan from seismic waveforms and travel times. Earth Planet. Sci. Lett., 229, 61-71, doi: 10.1016/j. eps1.2004.10.031. [Link]

Lallemand, S., Y. Font, H. Bijwaard, and H. Kao, 2001: New insights on 3-D plates interaction near Taiwan from tomography and tectonic implications. Tectonophysics, 335, 229-253, doi: 10.1016/S0040-1951(01)00071-3. [Link]

Lin, C. H., 2000: Thermal modeling of continental subduction and exhumation constrained by heat flow and seismicity in Taiwan. Tectonophysics, 324, 189-201, doi: 10.1016/S0040-1951(00)00117-7. [Link]

Lin, C. H., 2002: Active continental subduction and crustal exhumation: The Taiwan orogeny. Terr. Nova, 14, 281287, doi: 10.1046/j.1365-3121.2002.00421.x. [Link]

Lin, C. H., 2009: Compelling evidence of an aseismic slab beneath central Taiwan from a dense linear seismic array. Tectonophysics, 466, 205-212, doi: 10.1016/j. tecto.2007.11.029. [Link]

Lin, C. H., B. S. Huang, and R. J. Rau, 1999: Seismological evidence for a low-velocity layer within the subducted slab of southern Taiwan. Earth Planet. Sci. Lett., 174, 231-240, doi: 10.1016/S0012-821X(99)00255-1. [Link]

Malavieille, J., S. E. Lallemand, S. Dominguez, A. Deschamps, C. Y. Lu, C. S. Liu, P. Schnuerle, J. Angelier, J. Y. Collot, B. Deffontaines, M. Fournier, S. K. Hsu, J. P. Le Formal, S. Y. Liu, J. C. Sibuet, N. Thareau, F. 
Wang, and the ACT (Active Collision in Taiwan) Scientific Crew, 2002: Arc-continent collision in Taiwan: New marine observations and tectonic evolution. Spec. Pap. Geol.Soc. Am., 358, 189-213.

Seno, T., 1977: The instantaneous rotation vector of the Philippine Sea plate relative to the Eurasian plate. Tectonophysics, 42, 209-226, doi: 10.1016/00401951(77)90168-8. [Link]

Shin, T. C., K. W. Kuo, W. H. K. Lee, T. L. Teng, and Y. B. Tsai, 2000: A preliminary report on the 1999 Chi-Chi (Taiwan) earthquake. Seismol. Res. Lett., 71, 24-30, doi: 10.1785/gssrl.71.1.24. [Link]

Shin, T. C., C. H. Chang, H. C. Pu, H. W. Lin, and P. L. Leu, 2013: The Geophysical Database Management System in Taiwan. Terr. Atmos. Ocean. Sci., 24, 11-18, doi: 10.3319/TAO.2012.09.20.01(T). [Link]

Yang, T. F., T. Lee, C. H. Chen, S. N. Cheng, U. Knittel, R. S. Punongbayan, and A. R. Rasdas, 1996: A double island arc between Taiwan and Luzon: Consequence of ridge subduction. Tectonophysics, 258, 85-101, doi: 10.1016/0040-1951(95)00180-8. [Link]

Yu, S. B., H. Y. Chen, and L. C. Kuo, 1997: Velocity field of GPS stations in the Taiwan area. Tectonophysics, 274, 41-59, doi: 10.1016/S0040-1951(96)00297-1. [Link]

Zelt, C. A. and R. B. Smith, 1992: Seismic traveltime inversion for 2-D crustal velocity structure. Geophys. J. Int., 108, 16-34, doi: 10.1111/j.1365-246X.1992.tb00836.x. [Link] 